\title{
POLITYKA BRANDENBURSKA JANA III SOBIESKIEGO
}

\author{
Andrzej Kamieński http://orcid.org/0000-0002-5117-2537 \\ Instytut Historii Polskiej Akademii Nauk
}

\section{ABSTRACT \\ THE BRANDENBURG POLICY OF JOHN III SOBIESKI}

The Brandenburg policy of John III Sobieski was unfortunate and inconsistent. The Polish king, like his predecessors, did not have a political programmme towards the Hohenzollern monarchy. He took active steps in the Brandenburg direction only when a dynastic interest occurred. Such a stance was visible for the first time in the years 1675-1679. The change of policy towards Brandenburg-Prussia, conducted at the time by John III and based on his alliance with France and Sweden, did not bring him any benefits. It caused, however, many problems for Frederick William, the Brandenburg elector. After 1679, John III, as far as the Brandenburg direction was concerned, was in a clearly defensive position. He endeavoured to marry prince James with a rich protegee of the Hohenzollern family, Luisa Carolina of Radziwill. The efforts made in this regard ended in two humiliating defeats of the king: in 1681 and in 1688. The French diplomacy wanted to take advantage of the Berlin matrimonial affront of 1688 and tried to persuade John III to make a new attempt towards reclaiming the Duchy of Prussia. The king did not take up this idea anymore.

Keywords: John III Sobieski, Brandenburg-Prussia, Hohenzollerns, Duchy of Prussia, Baltic policy, Polish influence in the Baltic region, diplomacy.

Słowa kluczowe: Jan III Sobieski, Brandenburgia-Prusy, Hohenzollernowie, Księstwo Pruskie, polityka bałtycka, polskie wpływy nad Bałtykiem, dyplomacja.

Aby dokonać właściwej oceny polityki brandenburskiej Jana III Sobieskiego, musimy cofnąc się w czasie do jego poprzedników zasiadających na tronie polskim - Jana Kazimierza i Michała Korybuta Wiśniowieckiego. W historiografii polskiej przeważają opinie, że polityka tych władców wobec brandenbursko-pruskiej monarchii Hohenzollernów była co najmniej niedołężna, niefortunna i niekonsekwentna. Podkreśla się też, że to właśnie Jan III Sobieski, w przeciwieństwie do Jana Kazimierza i Michała Korybuta Wiśniowieckiego, dostrzegł narastające zagrożenie ze strony 
dworu berlińskiego oraz upomniał się o polską rację stanu nad Bałtykiem. Sądy te postaram się zweryfikować w niniejszym tekście.

Od uzyskania przez elektora brandenburskiego Fryderyka Wilhelma suwerenności w Księstwie Pruskim na mocy postanowień traktatu welawskiego z 19 września 1657 roku racją stanu monarchii Hohenzollernów było utrzymanie anarchii polskiej i słabej władzy królewskiej nad Wisłą poprzez podsycanie opozycji magnackiej i podkopywanie wśród szlachty zaufania do dworu warszawskiego. Założenia tej polityki określił Fryderyk Wilhelm w swoim testamencie sporządzonym 19 maja 1667 roku w Kölln nad Sprewą, a więc 10 lat po zdobyciu pełnej władzy nad Prusami Książęcymi. Zalecił w nim swoim następcom trzymanie się stale Rzeczypospolitej, która „nigdy nie wymiera”, i podkreślił, że przez takie zachowanie doprowadzą do tego, że królowie polscy będą musieli liczyć się z dworem berlińskim po wszystkie czasy. $Z$ treści tego rozporządzenia wynika jasno, że elektorowie brandenburscy mieli przyjmować rolę opiekunów polskich stronnictw magnackich znajdujących się $\mathrm{w}$ konflikcie $\mathrm{z}$ dworem warszawskim. To właśnie one utożsamiały wspomnianą w testamencie politycznym Rzeczpospolitą.

Rewizja polityki brandenburskiej względem państwa polsko-litewskiego, podyktowana koniecznością obrony wywalczonej w latach „,potopu” szwedzkiego suwerenności w Księstwie Pruskim, nie wywołała nad Wisłą pożądanej refleksji. Polscy monarchowie mogli szachować dwór berliński i neutralizować jego działalność na odcinku polskim poprzez stosowanie podobnych kroków. Należało konsekwentnie popierać stany Prus Książęcych i lenna lęborsko-bytowskiego przeciwko despotyzmowi Hohenzollerna oraz wyzyskiwać propagandowo niechęć mas szlacheckich do zaprowadzanego przez elektora Fryderyka Wilhelma absolutystycznego systemu rządów. Zarówno Jan Kazimierz, jak i Michał Korybut Wiśniowiecki zdawali sobie sprawę z atutu, jaki stanowiła aktywność polska na powierzonych władzy Hohenzollernów ziemiach. Niestety, zdobytą dzięki podjęciu sprawy stanów pruskich przewagę w kontaktach z elektorem zaprzepaszczali w niuansach polityki dynastycznej bądź krótkoterminowych, często iluzorycznych korzyściach.

Uwidoczniło się to już podczas rokowań polsko-brandenburskich prowadzonych w Bydgoszczy w listopadzie 1657 roku. Polska para królewska (Jan Kazimierz i Ludwika Maria) za wątpliwą pomoc elektora brandenburskiego w staraniach dotyczących sukcesji tronu przyznała wówczas Hohenzollernowi dodatkowe korzyści - lenno lęborsko-bytowskie, Elbląg i starostwo drahimskie jako zastaw za poniesione koszty wojenne. Mało odpowiedzialnie zachował się Jan Kazimierz również wobec stanów pruskich, które rozpoczęły swoje obrady 30 maja 1661 roku w Królewcu. Dyplomem wydanym 6 lipca 1661 roku potwierdził suwerenność elektora w Prusach i zwolnienie mieszkańców Księstwa od dawnych przysiąg, a następnie w dwóch listach z 30 czerwca 1662 roku wystosowanych do mieszkańców Królewca i przywódcy tamtejszej opozycji mieszczańskiej, Hieronymusa Rotha, obiecał obywatelom Prus Książęcych swoją pomoc, opowiedział się za utrzymaniem ich przywilejów oraz stwierdził, że uznał suwerenność Hohenzollerna tylko z konieczności. Kiedy malkontenci pruscy zaczęli przygotowywać się do akcji przeciwko elektorowi i podjęli zabiegi o uzyskanie pomocy militarnej z Polski, Jan Kazimierz wycofał się 
z wcześniejszych obietnic. 20 lipca 1662 roku wydał kurfirstowi deklarację, w której wyraził chęć przestrzegania traktatów welawsko-bydgoskich oraz ostrzegł Prusaków przed wszelkimi próbami buntu wobec Fryderyka Wilhelma. Ofiarą chwiejności polskiego króla padł łatwowierny Roth, porwany i wywieziony przez żołnierzy elektorskich z Księstwa Pruskiego, a następnie wtrącony do więzienia w twierdzy Peitz koło Chociebuża, gdzie dokonał żywota w 1678 roku. Opór landtagu królewieckiego wobec uznania suwerenności Hohenzollernów w Księstwie Pruskim został w ten sposób złamany. 18 października 1663 roku odbył się w Królewcu uroczysty hołd stanów pruskich, które złożyły przysięgę Fryderykowi Wilhelmowi jako władcy suwerennemu w Prusach Książęcych. Równocześnie komisarze polscy odebrali od stanów hołd ewentualny, zastrzegający prawa Rzeczypospolitej do Księstwa w razie wymarcia elektorskiej linii Hohenzollernów. Warto jeszcze przypomnieć wydarzenie, które miało miejsce krótko przed abdykacją Jana Kazimierza (16 września 1668 roku). Poprzedziła ją bowiem zgoda króla na zajęcie starostwa drahimskiego przez wojska elektora brandenburskiego. Najazd zbrojny Brandenburczyków na Drahim nastąpił 7 września 1668 roku. Trudno nazwać tę decyzję monarchy inaczej niż zdradą stanu.

Rażących zaniedbań na odcinku brandenbursko-pruskim dopuścił się także następca Jana Kazimierza, Michał Korybut Wiśniowiecki. Był on zwalczany przez powiązane $\mathrm{z}$ Wersalem stronnictwo magnackie i mógł z łatwością powiązać utrwalający się wśród szlachty nad Wisłą strach przed francuskim absolutyzmem z ówczesnym sojusznikiem Ludwika XIV - elektorem brandenburskim Fryderykiem Wilhelmem. Najlepsza ku temu okazja nadarzyła się wiosną 1670 roku, gdy szlachta wielkopolska wykryła związki Hohenzollerna z opozycją magnacką. Nadesłane do Wielkopolski przez biskupa chełmskiego Krzysztofa Żegockiego wieści o spisku przeciwko królowi Michałowi przygotowywanym przez sympatyków Francji w porozumieniu z elektorem i przy pomocy jego wojsk wzburzyły masy szlacheckie zgromadzone 20 maja 1670 roku na sejmiku relacyjnym w Środzie. Za koronny dowód knowań uznano szyfrowany list Jana Andrzeja Morsztyna do kasztelana poznańskiego Krzysztofa Grzymułtowskiego, o którym wiedziano, że jest przyjacielem kurfirsta. Rozwścieczona szlachta ciężko poraniła Grzymułtowskiego, a następnie zadeklarowała gotowość czynnej obrony tronu. Tymczasem król Michał nie potrafił nagłośnić tego incydentu, obnażyć prawdziwego oblicza Fryderyka Wilhelma, który zaczął wyrastać w oczach mas szlacheckich na obrońcę ,złotej wolności” i gwaranta swobód polskich. Miał także swój udział w tym, że Morsztyn i Grzymułtowski uniknęli surowej kary. Przyczynił się do tego również lider stronnictwa profrancuskiego, przyszły król Polski Jan Sobieski, udzielając kasztelanowi poznańskiemu azylu na Ukrainie.

Brak konsekwencji zauważamy również w przypadku posługiwania się przez króla Michała kartą stanów Prus Książęcych. Monarcha poparł postulaty tamtejszych stanów i otoczył opieką przywódcę opozycji antyelektorskiej pułkownika Christiana Ludwiga von Kalckstein zbiegłego do Polski w marcu 1670 roku. Przyczynił się także do wystąpienia Kalcksteina na sejmie w Warszawie 13 października 1670 roku z memoriałem przeciwko Hohenzollernowi, w którym pułkownik opisał prześladowania patriotów pruskich, łamanie przez kurfirsta przywilejów stanowych oraz wezwał parlamentarzystów do wsparcia Prusaków w walce z elektorem. Później 
jednak nie wykorzystał powszechnego oburzenia wywołanego porwaniem opozycjonisty przez ludzi elektorskich z Warszawy w końcu listopada 1670 roku. Zapomniał o gwałcie brandenburskim i w celu ratowania tronu oraz uzyskania od Hohenzollerna pomocy wojskowej przeciwko Turkom 24 marca 1672 roku odnowił z nim traktaty welawsko-bydgoskie. Kalckstein zapłacił najwyższą cenę za egoizm i krótkowzroczność monarchy oraz elit politycznych Rzeczypospolitej. 8 listopada 1672 roku został stracony w cytadeli kłajpedzkiej.

Błędy popełnione przez Jana Kazimierza i Michała Korybuta Wiśniowieckiego postawiły ich następcę Jana III Sobieskiego w bardzo trudnej sytuacji. Bez powstrzymania rozkładu ustroju prawno-politycznego Rzeczypospolitej i destrukcyjnej działalności koterii magnackich nie można było myśleć o prowadzeniu skutecznej polityki zagranicznej. Najlepszy czas na dokonanie niezbędnych reform został zmarnowany. Od „potopu” szwedzkiego, który zachwiał na krótko wiarą szlachty w doskonałość ustroju, minęło już kilkanaście lat. Swobodę ruchów coraz bardziej krępowały sąsiadujące z państwem polsko-litewskim monarchie niemieckie - Austria i Brandenburgia-Prusy. Na domiar złego Jan III Sobieski już na początku swego panowania dysponował bardzo ograniczonymi możliwościami wyzyskiwania do działań politycznych niezwykle przychylnie usposobionych do Polski stanów pruskich. Hohenzollern, w przeciwieństwie do królów polskich, wykorzystał czas, jaki minął od 1657 roku, i umocnił swoją pozycję w Księstwie Pruskim. Gdy ważyły się losy elekcji Sobieskiego nad Wisłą, doprowadził w Prusach Książęcych do decydujących rozstrzygnięć. W marcu 1674 roku zwołał landtag do Królewca i brutalnie złamał opór stanów pruskich w kwestiach podatkowych. Represjonował przywódcę opozycji szlacheckiej, Hansa Erharda von Brumsee, a 9 maja 1674 roku użył przeciwko mieszczanom królewieckim ponad 3700 żołnierzy, zmuszając ich do zapłacenia kontrybucji. Odtąd nie było już mowy o jawnym oporze Prusaków przeciwko absolutystycznym poczynaniom Hohenzollerna.

Obwołanie królem Polski i wielkim księciem Litwy Jana III Sobieskiego 21 maja 1674 roku nie wywołało u elektora brandenburskiego szczególnego zaniepokojenia. Fryderyk Wilhelm porozumiewał się z nim wielokrotnie podczas bezkrólewia za pośrednictwem swoich dyplomatów i nawet zapewnił - przypuszczalnie nieszczerze - o swoim poparciu. Dysponując rozbudowaną siecią informatorów, brał pod uwagę wyniesienie na tron hetmana, uchodzącego powszechnie za oddanego stronnika Francji. Nie zdołał wszakże zapobiec antybrandenburskim wystąpieniom posłów z Prus Królewskich. To za ich sprawą w zaprzysiężonych przez Jana III w dniu 5 czerwca 1674 roku paktach konwentach pojawił się obszerny zapis dotyczący konieczności respektowania przez elektora przywilejów stanowych w podlegającym królowi polskiemu lennie lęborsko-bytowskim, w tym prawa szlachty do uchwalania podatków tylko na jej sejmikach, za jej ogólnym przyzwoleniem. W tej sytuacji nowy władca Polski musiał odrzucić postulaty elektorskie dotyczące jak najszybszego zaprzysiężenia traktatów z 1657 roku, jak również dokonania renowacji lenna lęborsko-bytowskiego. Gotów był natomiast przyjąć list gratulacyjny Fryderyka Wilhelma z jego wotum, jakby suffragium, i dołączyć pismo do archiwum dokumentów królewskich. Jan III Sobieski mógł w ten sposób potwierdzić stare pretensje Hohenzollernów do 
udziału w elekcjach królów polskich. Zapobiegli temu jednak biskup krakowski Andrzej Trzebicki, zastępujący w obowiązkach zmarłego niedawno interreksa, prymasa Kazimierza Floriana Czartoryskiego, oraz marszałek sejmu elekcyjnego Benedykt Paweł Sapieha.

To ostatnie wydarzenie stanowi dowód na to, że Jan III Sobieski, wstępując na tron, nie miał sprecyzowanych planów antybrandenburskich. Rodziły się one powoli w ciągu następnych kilkunastu miesięcy pod wpływem przeobrażeń dokonujących się na arenie międzynarodowej. Elektor brandenburski związany politycznie z Ludwikiem XIV mógł uchodzić początkowo w oczach Sobieskiego nawet za potencjalnego sprzymierzeńca. Ten stan rzeczy zaczął ulegać zmianie za sprawą Hohenzollerna, który zerwał z Wersalem i 1 lipca 1674 roku związał się układem sojuszniczym z cesarzem, Hiszpanią i Niderlandami przeciwko Francji. Od tego momentu Sobieski stał się obiektem silnej agitacji ze strony Francji i Szwecji, państw zainteresowanych wciągnięciem Rzeczypospolitej do wojny przeciwko Fryderykowi Wilhelmowi. Początkowo odnosił się do tych planów z rezerwą, zasłaniając się koniecznością zakończenia wojny z Turcją i odwlekając decyzję na spokojniejszą przyszłość. W tym stanie rzeczy Ludwik XIV mógł posłużyć się tylko Szwedami. Ich najazd w grudniu 1674 roku na Marchię Brandenburską zmusił elektora brandenburskiego do natychmiastowego opuszczenia teatru działań wojennych w Alzacji i zajęcia się obroną własnego kraju. Fryderyk Wilhelm wyszedł z tych zmagań zwycięsko, pokonując wojska szwedzkie pod Fehrbellinem ( 28 czerwca 1675 roku) i wypierając je z okolic Berlina.

Tymczasem Jan III Sobieski podjął wreszcie próbę reorientacji polityki zagranicznej i zaczął myśleć o przejęciu dla siebie lub dla swojego syna Jakuba w dziedziczne władanie Prus Książęcych. Podstawową rolę w tych zamiarach miał odegrać związek z królem Ludwikiem XIV oraz jego aliantką Szwecją przeciwko elektorowi Fryderykowi Wilhelmowi, który - jak wiemy - należał w tym czasie do koalicji antyfrancuskiej. Dwór wersalski przeznaczył Polsce i Szwecji rolę sojuszników mających wykonać atak na wschodnie posiadłości Hohenzollerna, to jest na Marchię Brandenburską, brandenburską część Pomorza i Prusy Książęce. Jan III długo obawiał się, że król szwedzki Karol XI powróci do tradycji swoich wielkich poprzedników, Gustawa II Adolfa i Karola X Gustawa, i w razie sukcesów orężnych zajmie i zatrzyma dla siebie Księstwo Pruskie. Z tego powodu łatwiej królowi polskiemu było podpisać tajny traktat z Francją. Układ zawarty 11 czerwca 1675 roku w Jaworowie na Rusi Czerwonej gwarantował Sobieskiemu pomoc Ludwika XIV w zdobyciu Prus Książęcych oraz środki finansowe na prowadzenie wojny z Hohenzollernem. Burbon przeznaczył też kwotę 200000 liwrów na szybkie zakończenie wojny między Rzecząpospolitą a Portą. Kiedy 17 października 1676 roku król polski zawarł rozejm w Żurawnie z Turcją, sprawa rewindykacji Prus zaczęła stawać się realna. Warto podkreślić, że jeden z punktów układu z Osmanami zapewniał Sobieskiemu posiłki tureckie i tatarskie przeciwko wrogom Królestwa Polskiego. Zdaniem znawcy panowania Jana III, Zbigniewa Wójcika, chodziło tutaj przede wszystkim o Brandenburgię-Prusy, a dopiero w dalszej kolejności o Austrię i Rosję. 
Sobieski zwlekał z rozpuszczeniem wojska, ale nie podjął żadnych antybrandenburskich kroków, oglądając się na zgodę stanów. Fryderyk Wilhelm wykorzystał ten czas na zakulisowe intrygi oraz kaptowanie szlachty i zacieśnił swoje związki z antykrólewską opozycją. Pod wpływem argumentacji brandenburskiej większość opinii szlacheckiej opowiedziała się szybko za utrzymaniem pokoju z elektorem. $\mathrm{Na}$ potrzeby polskiej racji stanu nad Bałtykiem zwracali uwagę na sejmie warszawskim w 1677 roku tylko reprezentanci Prus Królewskich, zwłaszcza wojewoda pomorski Jan Ignacy Bąkowski i starosta pucki Kazimierz Rogala Zawadzki. Jan III, nie mogąc myśleć o skłonieniu stanów do wystąpienia przeciwko Brandenburgii-Prusom, zdecydował się na normalizację relacji z Hohenzollernem. 17 maja 1677 roku dokonał renowacji układów welawsko-bydgoskich. W tym samym dniu odbyło się też odnowienie lenna lęborsko-bytowskiego, choć na dokumencie wpisano datę późniejszą (18 maja).

Od tej chwili wszystkie działania Sobieskiego mające na celu rewindykację Prus Książęcych były podejmowane wyłącznie na drodze pozasejmowej. Król wciąż się łudził, że nadarzy się jeszcze jakaś okazja, że elektor brandenburski w wyniku działań wojennych znajdzie się za jakiś czas w poważnych tarapatach. Zgodził się wreszcie na współpracę ze Szwedami, ale chciał uzyskać w zamian jakąś gwarancję, że Prusy Książęce dostaną się w wyniku akcji zbrojnej w ręce polskie, a nie szwedzkie. 4 sierpnia 1677 roku podpisał w Gdańsku z posłem szwedzkim Andersem Liliehöökiem polsko-szwedzki traktat przymierza, ratyfikowany 18 października przez króla Karola XI. Układ zawarty w sekrecie przed stanami przewidywał wspólną akcję przeciwko Hohenzollernowi w Prusach Książęcych. Król szwedzki zobowiązał się zaatakować ten kraj w 8000-10 000 ludzi, król polski zaś wspomagać go korpusem liczącym od 6000 do 7000 wojska. Po zakończeniu kampanii Prusy Książęce miały przypaść królowi polskiemu i jego sukcesorom, a więc Jakubowi Sobieskiemu. Gwarantką układu była Francja.

Zgodnie z literą umowy zaczęto tworzyć polski korpus wojska. Duże zaliczki pieniężne dał na ten cel Jan III Sobieski, podskarbi wielki koronny Jan Andrzej Morsztyn i stolnik koronny Jan Wielopolski. Król działał jako osoba prywatna, bez upoważnienia Rzeczypospolitej, toteż organizacją zaciągów wojskowych zajmował się sam ambasador Francji w Polsce, markiz François de Béthune. Dowództwo nad korpusem powierzono także Francuzowi, administratorowi ekonomii malborskiej, pułkownikowi Henrykowi de Beaulieu. Jednocześnie Jan III Sobieski podjął zabiegi zmierzające do pozyskania przychylności stanów Prus Książęcych. Przyjmował malkontentów pruskich do służby dworskiej i wojskowej, nadawał im wysokie urzędy. Wśród obdarowanych przez króla znalazł się dawny współpracownik Christiana Ludwiga Kalcksteina, Johann Theodor von Schlieben, który postąpił 3 października 1677 roku na urząd wojewody inflanckiego.

Zakulisowa działalność Sobieskiego zaczęła przynosić konkretne rezultaty. Już w październiku 1677 roku zagrożony dywersją na tyłach swej armii elektor wyraził gotowość przekazania królewiczowi Jakubowi Sobieskiemu ziemi lęborskiej i bytowskiej za cenę neutralności króla polskiego. W końcu stycznia 1678 roku podbił tę ofertę, dorzucając jeszcze dla syna Jana III starostwo drahimskie oraz wyrażając 
gotowość scedowania na króla Polski swoich praw do Elbląga, które wynosiły 400000 talarów. Odrzucenie propozycji brandenburskiej należy uznać za poważny błąd Sobieskiego. Projekt rewindykacji Prus Książęcych utknął bowiem w martwym punkcie, choć pochłaniał spore środki finansowe. Żołnierze z korpusu przeznaczonego do wsparcia Szwedów stali bezczynnie w dobrach królewskich w Gniewie, Pucku i Malborku przez wiele miesięcy. Po tym, jak król Ludwik XIV przestał wypłacać subsydia na ich utrzymanie, siły te stopniały na jesieni 1678 roku do około 3000 ludzi. Król szwedzki spóźnił się ze swoim atakiem na Prusy Książęce o cały rok. Na domiar złego powierzył jego wykonanie nieudolnemu feldmarszałkowi Henrikowi Hornowi. Sobieski nie czekał już na dywersję na Prusy Książęce, która zakończyła się zupełną klęską Szwedów w styczniu i lutym 1679 roku. Na sejmie grodzieńskim 1678/1679 roku zrezygnował ze swych planów bałtyckich i wszedł na ścieżki polityki prohabsburskiej i antytureckiej. Polityka antybrandenburska prowadzona przez Jana III w latach 1675-1679 nie przyniosła mu żadnych korzyści. Zmusiła wszakże Fryderyka Wilhelma do ustawicznej czujności na Wschodzie i trzymania armii na Pomorzu lub w Prusach Książęcych. Konsekwencją absencji sił elektorskich w walkach nad Renem było opuszczenie Hohenzollerna w decydującej fazie wojny przez cesarza i Holandię oraz pozbawienie go owoców zwycięstwa nad Szwecją. W myśl traktatu pokojowego podpisanego 29 czerwca 1679 roku w Saint-Germain-en-Laye Hohenzollern musiał zwrócić Szwedom ziemie zdobyte podczas wojny wraz ze Szczecinem, Stralsundem, Rugią, Wolinem i Uznamem.

Relacje polsko-brandenburskie w latach 1679-1685/1686 nie były już tak dynamiczne. Jan III Sobieski, rozluźniając swe związki z Francją i zbliżając się do Austrii, znalazł się na odcinku brandenburskim w wyraźnej defensywie. Inicjatywę przejął elektor Fryderyk Wilhelm, który po podpisaniu w dniu 25 października 1679 roku w Saint-Germain-en-Laye traktatu ścisłego przymierza z Francją odgrywał rolę najbliższego współpracownika Ludwika XIV w sprawach polskich i niemieckich. Poparcie przez Wersal planu małżeństwa syna elektorskiego, margrabiego Ludwika Hohenzollerna, z jedyną córką i dziedziczką namiestnika Prus Książęcych Bogusława Radziwiłła przybliżyło Fryderyka Wilhelma do osiągnięcia ogromnych dóbr ziemskich i wpływów politycznych na Litwie oraz dało nadzieję na jeszcze skuteczniejszą walkę z Janem III. Król polski zainteresowany wydaniem Ludwiki Karoliny Radziwiłłówny za królewicza Jakuba Sobieskiego starał się tym projektom przeciwstawić. Tracił jednak grunt pod nogami po tym, jak odwrócili się od niego dotychczasowi stronnicy z partii profrancuskiej, tacy jak podskarbi wielki koronny Jan Andrzej Morsztyn, kanclerz wielki koronny Jan Wielopolski czy wojewoda poznański Krzysztof Grzymułtowski. Władcy Brandenburgii-Prus i Francji mogli w tej sytuacji zlekceważyć Jana III i postawić go przed faktem dokonanym. 7 stycznia 1681 roku Ludwika Karolina z Radziwiłłów została wydana za margrabiego Ludwika. Sobieski miał jeszcze nadzieję, że głosy oburzenia na elektora i małżeństwo radziwiłłowsko-hohenzollernowskie, które rozległy się na sejmie warszawskim rozpoczętym 14 stycznia 1681 roku, doprowadzą do wydania przez zgromadzenie konstytucji godzącej w dobra margrabiny i interesy dworu berlińskiego. Posłowie brandenburscy starali się udobruchać króla rozmaitymi korzyściami materialnymi. 
Na początku lutego 1681 roku zaproponowali Janowi III część fortuny po Bogusławie Radziwille - dobra Kopyś w województwie witebskim, które przynosiły ponoć 30000 talarów rocznego dochodu. Król miał jednak inne życzenie - domagał się od elektora zwrotu starostwa drahimskiego. Dyplomata brandenburski, nie mogąc się na to zgodzić, uciekł się do gróźb i oświadczył Sobieskiemu, że wrogie działania przeciw dworowi berlińskiemu skazane są na porażkę z powodu porozumienia hohenzollernowsko-burbońskiego.

Jan III skupił się wobec tego na targach o uzyskanie jak najwyższego odszkodowania pieniężnego. Strona brandenburska godziła się na takie rozwiązanie sporu, oferując Sobieskiemu 18 maja 1681 roku za pośrednictwem biskupa warmińskiego Michała Radziejowskiego kwotę 100000 guldenów „w dobrym srebrze”. Monarcha polski jednak grał na zwłokę, wyraźnie pokrzepiony opowiedzeniem się sejmu za wojną z Turcją i uchwałami dotyczącymi wystawienia przez Polaków 36000 żołnierzy, a przez Litwinów od 10000 do 12000 zbrojnych. Przeciągające się rokowania $\mathrm{z}$ dworem polskim oraz nadchodzące od rozmaitych informatorów wieści o tym, że Jan III zaatakuje najpierw Prusy Książęce, a dopiero potem ziemie sułtana tureckiego, skłoniły Fryderyka Wilhelma do podjęcia radykalnych środków. Zerwanie sejmu w końcu maja 1681 roku z inspiracji dworu berlińskiego przy pomocy ludzi dwóch magnatów - Krzysztofa Grzymułtowskiego i Michała Kazimierza Paca - oddaliło perspektywę zawiązania ligi polsko-austriackiej i zrealizowania dzięki Habsburgom oraz zwycięskiej wojnie z Turcją planów dynastycznych polskiego dworu.

Jan III Sobieski otrzymał od Brandenburczyka surową lekcję, ale wyciągnął z niej właściwe wnioski. Dał do zrozumienia Hohenzollernowi, że wycofa się ze sporu w zamian za kwotę 50000 talarów. Zaproponował też, aby zawarcie umowy w sprawie dóbr Ludwiki Karoliny z Radziwiłłów nastąpiło podczas najbliższego sejmu zwołanego na dzień 27 stycznia 1683 roku w Warszawie. Doszło tam do transakcji wiązanej. Dzięki biernej postawie dyplomacji brandenburskiej Jan III Sobieski zdolał przeforsować na sejmie przymierze z cesarzem Leopoldem I i ruszyć na odsiecz Wiednia. W zamian za to pozostał głuchy na żądania dotyczące poddania twierdz znajdujących się w dobrach Radziwiłłówny ścisłej kontroli Rzeczypospolitej. Zgodził się też na to, aby najbliższa rodzina Fryderyka Wilhelma rozporządzała ogromnymi dobrami ziemskimi na Litwie i Podlasiu. Traktat $w$ tej sprawie uzgodniony podczas sejmu podpisano tuż po zakończeniu zgromadzenia, 14 maja 1683 roku. W myśl porozumienia król polski uzyskał 40000 talarów jako umowne odszkodowanie za dobra radziwiłłowskie. Z obawy przed reakcją Francji obie strony zobowiązały się do zachowania traktatu w tajemnicy.

Przyjaźń między Sobieskim a Berlinem była jednak nieszczera. Pozostający w sojuszu z Francją elektor nie spieszył się z wysyłaniem posiłków wojskowych dla Jana III, choć był do tego zobowiązany traktatami z 1657 roku. Nie mogąc pomagać skonfliktowanemu z Wersalem Habsburgowi, sprytnie wybrnął z całej sprawy. Brandenburski korpus posiłkowy, którym dowodził pułkownik Wolfgang Christoph Truchseß baron von Waldburg, dotarł do obozu polskiego mocno spóźniony, bo dopiero 12 października 1683 roku. Przypomnijmy, że decydująca o losach cesarza i Wiednia bitwa pod Kahlenbergiem rozegrała się miesiąc wcześniej, 12 września. 
Związek państwa polsko-litewskiego z Austrią, zacieśniony w 1684 roku więzami Ligi Świętej i zerwaniem stosunków dyplomatycznych z Francją, nie przyniósł Sobieskiemu spodziewanych korzyści. Habsburgowie nie chcieli bowiem popierać planów dynastycznych Jana III ani dzielić się z nim ziemiami zdobytymi od Turków. Rozczarowany relacją z cesarzem władca Polski rozpoczął zabiegi o odnowienie przyjaźni z Francją. Prosił o pośrednictwo w tej sprawie Fryderyka Wilhelma. Ten jednak udzielał dworowi polskiemu tylko pozornej pomocy. W rzeczywistości wspierał potajemnie opozycję antykrólewską broniącą interesów habsburskich i Ligi Świętej.

Odnowienie przyjaźni między Sobieskim a Ludwikiem XIV zainicjowane legacją Jana Wielopolskiego do Francji w październiku 1685 roku zbiegło się w czasie $\mathrm{z}$ reorientacją polityki brandenburskiej. Układy zawarte przez elektora $\mathrm{z}$ cesarzem 25 grudnia 1685 roku i 22 marca 1686 roku usytuowały Brandenburgię-Prusy ponownie w gronie wrogów Wersalu. Elektor zobowiązał się w tych umowach do wspierania cesarza Leopolda I w sprawach Rzeszy i udzielania mu pomocy wojskowej, uzyskując w zamian od Hofburga wysokie subsydia pieniężne oraz obietnicę wspólnej obrony nietykalności wolnej elekcji w Polsce. W ten sposób sygnatariusze porozumień wykluczyli milcząco kandydaturę Jakuba Sobieskiego. Jan III nie mógł już także liczyć na pomoc Szwecji, która 10 lutego 1686 roku zawarła przymierze $z$ elektorem brandenburskim. W tajnej części tego układu znalazł się punkt zobowiązujący obie strony porozumienia do stania na straży praw i przywilejów Rzeczypospolitej. Hohenzollern święcił również sukcesy dyplomatyczne na odcinku wschodnim. 22 lutego 1686 roku zainicjował akcję mediacyjną na dworze władców Rosji, Iwana V i Piotra I, przyczyniając się do wynegocjowania wiecznego pokoju między Rzecząpospolitą a Rosją oraz przystąpienia carów do koalicji antytureckiej.

Po przejęciu kontroli nad dobrami Radziwiłłówny i ograniczeniu Sobieskiemu swobody ruchów na arenie międzynarodowej wypadało Fryderykowi Wilhelmowi oczekiwać ze spokojem na śmierć polskiego króla i najbliższe bezkrólewie. Na drodze do zrealizowania dynastycznych planów domu brandenburskiego stanął jednak zły los. 7 kwietnia 1687 roku zmarł nagle margrabia Ludwik, a 9 maja 1688 roku Fryderyk Wilhelm. Następca Fryderyka Wilhelma, Fryderyk III, musiał zabiegać na dworze polskim o potwierdzenie traktatów z 1657 roku oraz o udział przedstawicieli Polski w hołdzie stanów Prus Książęcych, od którego zależało uznanie sukcesji w tym kraju nowego władcy. Wszystko to stawiało Sobieskiego w znakomitej pozycji przetargowej i stwarzało szansę na naprawienie zaniedbań popełnionych w polityce brandenburskiej w ciągu ostatnich lat. Jan III zwietrzył natychmiast okazję do zrealizowania planów dynastycznych i podjął kroki zmierzające do wydania bogatej wdowy po margrabim Ludwiku za królewicza Jakuba. Majętności Ludwiki Karoliny z Radziwiłłów zapewniłyby królewiczowi widoki na królewską koronę, a dworowi polskiemu ogromne środki finansowe do walki z opozycją. W końcu XVII wieku, już po przejęciu przez dom brandenburski w latach 1687-1688 Taurogów i dóbr serejskich, liczyły one 18 miast, 1091 wsi i 134 zaścianki. Wydawało się, że nowy elektor nie będzie czynił Janowi III żadnych przeszkód. 8 lipca 1688 roku pojawił się w Berlinie incognito królewicz Jakub i uzyskał zgodę Fryderyka III na ożenek z Ludwiką 
Karoliną. W ślad za tym 25 lipca Radziwiłłówna zobowiązała się na piśmie pod groźbą utraty wszystkich swoich dóbr ziemskich przyjechać we wrześniu do Polski i oddać swą rękę królewiczowi. Zwycięstwo polskiego dworu zdawało się zapewnione.

Wdzięczny za pomoc elektora król polski przestał domagać się od Fryderyka III zadośćuczynienia pretensjom Rzeczypospolitej i szybko zakończył negocjacje prowadzone w Wilanowie z dyplomatami brandenburskimi. 29 lipca 1688 roku odnowił traktaty welawsko-bydgoskie bez odwoływania się do sejmu oraz wyznaczył komisarzy dla asysty przy hołdzie stanów Prus Książęcych. Interesy dynastyczne Sobieskich wzięły górę nad polską racją stanu. Spotkała za to króla niespodziewana kara. Okazało się bowiem, że młody Hohenzollern umiejętnie wykorzystał rozgorączkowanie Jana III i wyprowadził go w pole. 6 sierpnia 1688 roku przyjechał do Berlina książę neuburski Karol Filip i 10 sierpnia wziął z margrabiną Ludwiką Karoliną ślub w domu posła cesarskiego.

Berliński afront matrymonialny i ośmieszenie Sobieskich przy pomocy dyplomatów głównego sojusznika Jana III w Lidze Świętej - cesarza - wywołały nad Wisłą falę oburzenia. Na sejmie warszawskim 1688/1689 roku doszło do lawiny antybrandenburskich i antyhabsburskich wystąpień. Sobieski nie zdołał tego jednak wykorzystać, gdyż popierana przez Wiedeń, Berlin i Stolicę Apostolską opozycja magnacka doprowadziła do zerwania zgromadzenia. Dyplomacja francuska nakłaniała Jana III do podjęcia na nowo próby rewindykacji Prus Książęcych i dawała mu do zrozumienia, że do wykonania dywersji pruskiej szykuje się już Dania. Władca Polski odnosił się do tego planu z dużą ostrożnością, uzależniając atak na Prusy Książęce od stanowiska Szwecji, która sprzyjała wówczas Hohenzollernowi. Mimo ograniczonych możliwości istniała nadal szansa na wytargowanie od dworu berlińskiego znacznych ustępstw. Fryderyk III zajęty wraz z cesarzem wojną z Francją nad Renem musiał odroczyć hołd stanów pruskich. Można było wykorzystać nieobecność kurfirsta i pobudzić przy pomocy agentów francuskich pruską opozycję stanową lub przynajmniej zażądać rozpatrzenia przez Fryderyka III pretensji polskich przed wysłaniem do Królewca komisarzy na ceremonię hołdu. Tak się jednak nie stało. Ponownie zwyciężył interes dynastyczny. Po odrzuceniu przez Ludwika XIV propozycji małżeństwa królewicza Jakuba z przedstawicielką dynastii Burbonów dwór polski opowiedział się za sfinalizowaniem oferty matrymonialnej Hofburga (ożenek Jakuba Sobieskiego z Jadwigą Elżbietą, która była siostrą cesarzowej i księcia neuburskiego Karola Filipa, bohatera afrontu berlińskiego). Zacieśnił stosunki z Habsburgami i uregulował do końca relacje z sojusznikiem cesarza - Fryderykiem III. 24 maja 1690 roku stany Prus Książęcych złożyły hołd poddańczy Hohenzollernowi w obecności komisarzy Rzeczypospolitej - Hieronima Lubomirskiego i Stanisława Antoniego Szczuki.

Po zmarnotrawieniu przez Jana III okresu przewagi w relacjach z dworem berlińskim stosunki między dwoma państwami weszły w stan stagnacji. Sobieski usiłował realizować swoje koncepcje dynastyczne na podstawie sojuszu z cesarzem i dlatego celowo odkładał na później wszystkie sprawy sporne z Hohenzollernem. Nie zdołano już do nich powrócić za życia polskiego króla. Politykę brandenburską Jana III starała się jeszcze ożywić Francja, która chciała wykorzystać kolejne rozczarowanie króla do Habsburgów po klęsce wyprawy polskiej do Mołdawii w 1691 roku. 
Antybrandenburski i antyhabsburski układ z Ludwikiem XIV nie wszedł jednak w życie. Niepowodzeniem zakończyły się także próby zainicjowania antybrandenburskiej polityki nad Bałtykiem i włączenia państwa polsko-litewskiego do sojuszu z Koronami Północy - Danią i Szwecją z lat 1692-1694. Sobieski był już niezdolny do prowadzenia samodzielnej polityki. Zmarł w 1696 roku, pozostawiając relacje z Brandenburgią-Prusami w mocno zaniedbanym stanie.

Przechodząc do uwag końcowych na temat polityki brandenburskiej Jana III Sobieskiego, należy stwierdzić, że król polski, podobnie jak jego poprzednicy, nie miał programu politycznego wobec monarchii Hohenzollernów. Kontakty z dworem berlińskim i względy racji stanu nad Bałtykiem schodziły często u Jana III na daleki plan. Podejmował on aktywne działania na odcinku brandenburskim tylko wtedy, gdy pojawiał się interes dynastyczny - perspektywa wzmocnienia pozycji Sobieskich poprzez rewindykację Prus Książęcych bądź ożenek królewicza Jakuba z bogatą podopieczną Hohenzollernów, Ludwiką Karoliną z Radziwiłłów. Wszystkie wysiłki królewskie okazały się bezskuteczne. Dwór elektorski konsekwentnie wykorzystywał bowiem wady ustrojowe Rzeczypospolitej, polityczny dualizm celów polskiego władcy i szlachty oraz szachował Jana III przy pomocy opozycji magnackiej.

\section{BIBLIOGRAFIA}

\section{Źródła drukowane}

Archiwum spraw zagranicznych francuskie do dziejów Jana Trzeciego, t. 1-3, wyd. K. Waliszewski, Kraków 1879-1884 (Acta historia res gestas Poloniae illustrantia, t. 3, 5, 7). Kurbrandenburgs Staatsverträge von 1601 bis 1700, Hrsg. Th. von Moerner, Berlin 1867. Urkunden und Actenstücke zur Geschichte des Kurfürsten Friedrich Wilhelm von Branden-

burg, Bde. 1-23, Hrsg. B. Erdmannsdörffer et al., Berlin-Leipzig 1864-1930.

Woliński J., Traktat gdański 1677 r., „Teki Archiwalne” 1957, t. 5, s. 173-182.

\section{Opracowania}

Hein M., Johann von Hoverbeck. Ein Diplomatenleben aus der Zeit des Grossen Kurfürsten, Königsberg Pr. 1925.

Helcel A.Z., O dwukrotnym zamężciu ks. Ludwiki Karoliny Radziwiłtównej i wyniktych stąd w Polsce zamieszkach, Kraków 1857.

Jarochowski K., Brandenburgia i Polska w pierwszych latach po traktacie oliwskim [w:] idem, Nowe opowiadania i studya historyczne, Warszawa 1882, s. 175-247.

Jarochowski K., Sprawa Kalksteina 1670-1672, Warszawa 1883.

Kamieński A., Kto zerwat sejm warszawski w 1681 roku?, „Czasy Nowożytne” 2017, t. 30, s. $87-108$. 
Kamieński A., Polska a Brandenburgia-Prusy w drugiej połowie XVII wieku. Dzieje polityczne, Poznań 2002.

Kamieński A., Stany Prus Ksiązęcych wobec rzadów brandenburskich $w$ drugiej połowie XVII wieku, Olsztyn 1995.

Kamińska A., Brandenburg-Prussia and Poland. A Study in Diplomatic History (16691672), Marburg an der Lahn 1983.

Kamińska-Linderska A., Między Polska a Brandenburgia. Sprawa lenna lęborsko-bytowskiego w drugiej połowie XVII w., Wrocław-Warszawa 1966.

Komaszyński M., Jan III Sobieski a Battyk, Gdańsk 1983.

Lekus M., Der Große Kurfürst und der polnische Thron, Berlin 1929.

Lesiński J., Spory o dobra neuburskie, „Miscellanea Historico-Archivistica” 1996, t. 6, s. $95-132$.

Matwijowski K., Pierwsze sejmy z czasów Jana III Sobieskiego, Wrocław 1976.

Matwijowski K., Sejm grodzieński 1678-1679, Wrocław 1985.

Opgenoorth E., Friedrich Wilhelm. Der Grosse Kurfürst von Brandenburg. Eine politische Biographie, Bde. 1-2, Göttingen-Frankfurt am Main-Zürich 1971-1978.

Philippson M., Der Große Kurfürst Friedrich Wilhelm von Brandenburg, Bde. 1-3, Berlin 1897-1903.

Piwarski K., Dzieje polityczne Prus Wschodnich (1621-1772), Gdynia 1938.

Piwarski K., Hołdy pruskie, „Roczniki Historyczne” 1956, R. 21, s. 151-174.

Piwarski K., Jan III Sobieski wobec spraw battyckich w latach 1693-1694, „Rocznik Gdański" 1933-1934, t. 7-8, s. 183-207.

Piwarski K., Polityka baltycka Jana III Sobieskiego w latach 1675-1679 [w:] Księga pamiątkowa ku czci profesora dra Wactawa Sobieskiego, t. 1, Kraków 1932, s. 197-265.

Piwarski K., Polska a Francja po roku 1683, Kraków 1933.

Piwarski K., Sprawa pruska za Jana III Sobieskiego (1688-1689), „Kwartalnik Historyczny" 1929, R. 43, t. 1 , s. 153-186.

Prutz H., Französisch-polnische Umtriebe in Ostpreussen, „Deutsche Zeitschrift für Geschichtswissenschaft" 1889, Bd. 1, s. 429-442.

Schiemann T., Luise Charlotte Radziwil, Markgräfin von Brandenburg, „Forschungen zur Brandenburgischen und Preußischen Geschichte" 1890, Bd. 3, s. 125-168.

Wijaczka J., Traktat welawsko-bydgoski - próba oceny [w:] Rzeczpospolita w latach potopu, red. J. Muszyńska, J. Wijaczka, Kielce 1996, s. 49-74.

Woliński J., Sprawa pruska 1674-1675 i traktat jaworowski [w:] idem, Z dziejów wojny i polityki w dobie Jana Sobieskiego, Warszawa 1960, s. 16-56.

Wójcik Z., Jan Sobieski 1629-1696, Warszawa 1983.

Wójcik Z., Rzeczpospolita wobec Turcji i Rosji 1674-1679. Studium z dziejów polskiej polityki zagranicznej, Wrocław-Warszawa-Kraków 1976. 